\title{
Synthesis, Characterization and Kinetics of Catalytically Active Molecularly Imprinted Polymers for the Selective Recognition of 4-Aminophenol
}

\author{
Wilney J. R. Santos, ${ }^{a}$ Phabyanno R. Lima, ${ }^{a}$ César R. T. Tarley ${ }^{b}$ and Lauro T. Kubota*,a \\ ${ }^{a}$ Departamento de Química Analítica, Instituto de Química, Universidade Estadual de Campinas, \\ 13083-970 Campinas-SP, Brazil
}

${ }^{b}$ Departamento de Ciências Exatas, Universidade Federal de Alfenas, 37130-000 Alfenas-MG, Brazil

\begin{abstract}
No presente trabalho um polímero com impressão molecular (MIP) seletivo para 4-aminofenol (4-APh) foi sintetizado através de técnica de polimerização em bulk. A polimerização foi realizada em tubo de vidro contendo 4-APh, Fe(III)protoporfrina(IX) (hemina, Fe(III)PPIX), ácido metacrílico (MAA), etileno glicol dimetacrilato (EGDMA) e 2,2'-azo-bis-iso-butironitrila (AIBN). O bloco de polímero foi moído e peneirado $(106 \mu \mathrm{m})$ e o 4-APh foi removido das partículas do polímero pela extração com solução de metanol/ácido acético $(4: 1, \mathrm{v} / \mathrm{v})$, deixando uma cavidade nas partículas do polímero. A hemina foi usada como um material sintético para imitar o centro ativo da peroxidase, criando um polímero com impressão molecular cataliticamente ativo. Os polímeros foram caracterizados por espectroscopia no infravermelho, análises termogravimétricas, microscopia eletrônica de varredura e análise do tamanho das partículas. O desempenho enzimático do polímero impresso foi avaliado baseado em parâmetros cinéticos incluindo $V_{\max }$ e constante de Michaelis-Menten obtidas pelo gráfico de Lineweaver-Burk.
\end{abstract}

In the present work a selective molecularly imprinted polymer (MIP) for 4-aminophenol (4-APh) was synthesized by the bulk polymerization technique. Polymerization was carried out in a glass tube containing 4-APh, Fe(III)protoporphyrin(IX) (hemin, Fe(III)PPIX), methacrylic acid (MAA), ethylene glycol dimethacrylate (EGDMA) and 2,2'-azo-bis-iso-butyronitrile (AIBN). The polymer block was ground and sieved $(106 \mu \mathrm{m})$ and the 4 -APh was removed from the polymer particles by leaching with a methanol/acetic acid $(4: 1, \mathrm{v} / \mathrm{v})$ solution, which leaves a cavity in the polymer particles. Hemin was used as a synthetic material to mimic the active center of peroxidase creating a catalytically active molecularly imprinted polymer. The polymers were characterized by infrared spectroscopy, thermogravimetric analysis, scanning electron microscopy and particle size analysis. The enzymatic performance of the imprinted polymer was evaluated based on kinetic parameters including $V_{\max }$ and the Michaelis-Menten constant obtained from Lineweaver-Burk plots.

Keywords: molecularly imprinted polymers (MIP), hemin, 4-aminophenol, MichaelisMenten

\section{Introduction}

Molecular imprinting is a useful technique for the preparation of ligand-selective cavities in synthetic polymer matrices. ${ }^{1-3}$ Recently, the technique has attracted significant interest from a large number of areas within chemistry and the analytical sciences due to the relative ease with which these polymers may be prepared, the range of template structures that are amenable for use and the apparent mechanical and chemical stability of the types of polymers generally synthesized.

*e-mail: kubota@iqm.unicamp.br
Briefly, the technique may be described as follows. A template molecule is allowed to form reversible interactions (covalent or non-covalent) with suitable functionalized monomers in the presence of a cross-linking monomer. Polymerization affords a highly cross-linked macroporous polymer containing cavities with sites varying complementarily to the template. Removal of the template by competitive extraction procedures renders a material with the capacity to selectively re-adsorb the template. The selective recognition sites present in the molecularly imprinted polymers (MIPs) are attributed to the formation of either reversible covalent or non-covalent complexes in solution between a template molecule (the compound for which 
recognition is desired) and the functionalized monomers, which are subsequently fixed through polymerization using an excess of cross-linker to yield a rigid polymer network. $^{4}$

MIPs have been shown to possess ligand-recognition characteristics comparable to those observed in biological recognition systems, e.g. antibody-antigen, substrateenzyme. One of the major advantages of MIPs, relative to their biological counterparts, is their mechanical and chemical stability. A number of studies have reported the use of MIPs in a range of extreme environments (high temperatures, extremes of $\mathrm{pH}$ and ionic strength) unsuitable for use in conjunction with their biological macromolecular counterparts such as antibodies, receptor proteins and enzymes. ${ }^{5}$ Thus, MIPs have been applied for bioseparations, diagnostic assays, biosensors and catalysis. MIPs have also been employed in efforts to construct polymeric materials for synthetic enzyme-mimic catalysis applications. A detailed review about this subject ${ }^{6}$ and a few applications of MIPs in catalysis ${ }^{7-14}$ have been reported.

In a previous work, a new type of catalytically active polymer containing Fe(III)protoporphyrin(IX) (hemin, Fe(III) PPIX) as the catalytic center has been designed and prepared by molecular imprinting technology. ${ }^{15}$ The result indicates that MIP showed recognition capability for targeted molecule because of the size and arrangement of the functional groups in the cavity. For this purpose, hemin was used as a synthetic material with peroxidase-like activity in the synthesis of the MIP. Hemin may be found as a common catalytically active site in hemoproteins like hemoglobin, myoglobin, cytochromes and peroxidases. ${ }^{16-18}$ Iron porphyrins are biocatalysts, which catalyze oxidative reactions by decomposing hydrogen peroxide at the expense of various substrates, such as phenols and amides. ${ }^{19}$ Thus, a peroxidase-like MIP that efficiently catalyzes the oxidation of 4-aminophenol (4-APh) with considerable substrate specificity in the presence of hydrogen peroxide using a flow injection analysis system coupled to amperometric detection was described. Complementing these results, in the present work, presents the characterization by several physical techniques of the MIP, as well as, parameters such as the specificity, enzyme-mimic activity catalytic effects and Michaelis-Menten kinetics were evaluated.

\section{Experimental}

\section{Materials and chemicals}

All solvents and other chemicals were of analytical grade. 4-Aminophenol (4-APh), Fe(III)protoporphyrin(IX) (hemin, Fe(III)PPIX), methacrylic acid (MAA), ethylene glycol dimethacrylate (EGDMA), 2,2'-azo-bis-iso- butyronitrile (AIBN) were purchased from Sigma-Aldrich (Steinheim, Germany). Methanol and acetic acid were purchased from Tedia (Rio de Janeiro, Brazil). A Tris-HCl buffer solution at a concentration of $0.1 \mathrm{~mol} \mathrm{dm}^{-3}$ was used without further purification and was purchased from Merck (Darmstadt, Germany).

All solutions were prepared using water from a Millipore (Billerica, MA, USA) Milli-Q purification system.

\section{Preparation of imprinted polymer}

The preparation of imprinted polymer was performed as follows. Typically, the template molecule 4-APh $(45.0 \mu \mathrm{mol})$, and corresponding amounts of the functional monomer hemin $(30.0 \mu \mathrm{mol})$ and MAA $(450.0 \mu \mathrm{mol})$ were added to chloroform/DMSO $(1: 1, \mathrm{v} / \mathrm{v})$ in a thick-walled glass tube, and the cross-linker EGDMA (7.95 mmol) and the initiator AIBN $(0.18 \mathrm{mmol})$ were then added. The tube was sealed after the solution was sonicated under a nitrogen atmosphere for $10 \mathrm{~min}$ and it was then immersed in a $70{ }^{\circ} \mathrm{C}$ water bath to react for $24 \mathrm{~h}$. The bulk polymer was crushed, ground and sieved to pass through a $106 \mu \mathrm{m}$ sieve. The polymer was washed with methanol: acetic acid (4:1, v/v) for template removal, in accordance with previous work. ${ }^{15,20}$ After this step, the polymer was dried at room temperature for $12 \mathrm{~h}$. Corresponding blank polymer (NIP - non imprinted polymers) as control was prepared in parallel, without the template (4-APh) and treated in the same manner.

\section{Apparatus}

Amperometric measurements were carried out with an Autolab® PGSTAT-12 potentiostat (Eco Chemie B.V., The Netherlands) equipped with a wall-jet electrochemical cell using glassy carbon as the working electrode, an $\mathrm{Ag} / \mathrm{AgCl}$ as the reference electrode, and a platinum wire as the auxiliary electrode. The solutions were propelled by a peristaltic pump from Ismatec (Zurich, Switzerland), with silicone tubes. A home-made injector of Teflon ${ }^{\circledR}$ (PTFE, polytetrafluoroethylene) was used for the sampling and injection steps. A minicolumn (3 cm in length) made of polyethylene with two glass wool plugs was used to hold the MIP during the sampling and injection steps. ${ }^{15}$ All experiments were carried out at room temperature by applying the intended operating potential. Currents were allowed to reach a stable baseline prior to the amperometric monitoring.

The morphological characteristics of the MIP were evaluated by scanning electron microscopy (SEM), using a JEOL JSM-6360 LV scanning electron microscope (Tokyo, 
Japan) with an electron acceleration voltage of $20 \mathrm{kV}$. The samples were previously coated by a thin gold layer in a Bal-Tec MED 020 equipment.

The pore parameters and surface area of the MIPs were measured using an ASAP 2010 equipment (Micromeritics, Atlanta, USA). A quantity of $100 \mathrm{mg}$ of dry polymer was used and degassed at $100{ }^{\circ} \mathrm{C}$ under nitrogen for approximately $4 \mathrm{~h}$ prior to the measurement. The specific surface area was calculated using the BET method. ${ }^{21}$ The pore size distribution was determined by the Barrett-JoynerHalenda (BJH) method. ${ }^{21}$

IR spectra of ground polymer were recorded on a Bomem Michelson MB-102 spectrometer using $\mathrm{KBr}$ pellets in the wavelength range of $400-4000 \mathrm{~cm}^{-1}$.

The thermal analysis of the polymer was carried out on a model TA Instruments 2950 thermogravimetric (TG) - differential thermal analyser (DTA). About $5 \mathrm{mg}$ of the ground polymer was heated at a heating rate of $5{ }^{\circ} \mathrm{C} \mathrm{min}^{-1}$ from ambient temperature to $600{ }^{\circ} \mathrm{C}$ under a nitrogen atmosphere (flow rate $=20 \mathrm{~mL} \mathrm{~min}^{-1}$ ) and the corresponding TG-DTA curves were obtained.

\section{Catalytic activity and kinetic measurement of imprinted polymers}

Hemin (active site: $\mathrm{Fe}^{3+}$ protoporphyrin) oxidized by hydrogen peroxide can be reduced by $4-\mathrm{APh}$; the phenol is largely converted into quinone and/or a related free radicals. These products are usually electroactive and can be reduced on the electrode surface at a potential of close to $0 \mathrm{~V} v s$. $\mathrm{Ag} / \mathrm{AgCl}$. In this work, the catalytic reactions were carried out in Tris- $\mathrm{HCl}$ buffer $\left(0.1 \mathrm{mmol} \mathrm{L}^{-1}\right.$, $\mathrm{pH}$ 8.0) using a flow injection analysis system coupled to amperometric detector. The responses were evaluated by their peak heights, which were proportional to the analyte concentration in the sample.

In order to verify the behavior of the system, kinetic parameters such as the Michaelis-Menten constant $(\mathrm{Km})$ and maximum rate $\left(\mathrm{V}_{\max }\right)$ were also evaluated by employing the Lineweaver-Burk graph. ${ }^{22}$

\section{Results and Discussion}

\section{Polymer synthesis}

4-Aminophenol imprinted polymers were synthesized, as described in the experimental section, by a reaction based on non-covalent approach. The MIP particles were synthesized by bulk polymerization. The ground polymers were sieved and the fraction that fell in the size range of $106 \mu \mathrm{m}$ were used throughout the study.

\section{Characterization studies}

Unleached and leached ion imprinted polymer particles obtained using bulk polymerization were subjected to characterization by scanning electron microscopy (SEM), the BET method, FT-IR and thermogravimetric (TG) and differential thermal (DTA) analysis.

The SEM in Figure 1 clearly shows that pores were embedded in the network of the MIP, and that there were substantial differences in morphology between the MIP and NIP. The NIP had a smoother structure with small cavities and surface area than those of the MIP (Table1), which indicates that the increase of surface area of MIP was because of imprinting. This is also consistent with earlier results reported by Bruggemann ${ }^{14}$ that MIP tends to have higher surface areas than the corresponding NIP. Moreover, the surface area of the leached MIP showed a large increase compared with that of the imprinted polymers without extraction.
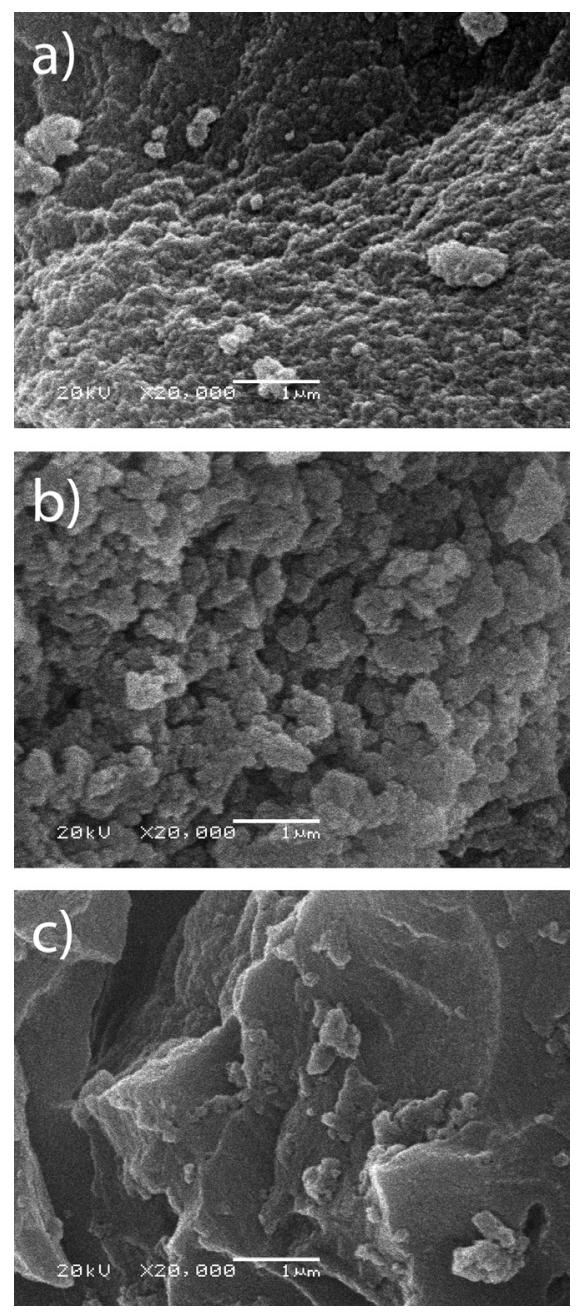

Figure 1. Scanning electron micrographs of the unleached (a) and leached (b) 4-APh imprinted polymer and of NIP (c) particles. 
Table 1. Comparison of the morphological characteristics of the MIPs and related control NIP

\begin{tabular}{lccc}
\hline Polymer & $\begin{array}{c}\text { Surface area/ } \\
\left(\mathrm{m}^{2} / \mathrm{g}\right)\end{array}$ & $\begin{array}{c}\text { Total pore } \\
\text { volume/ }\left(\mathrm{cm}^{3} / \mathrm{g}\right)\end{array}$ & $\begin{array}{c}\text { Average pore } \\
\text { diameter/(nm) }\end{array}$ \\
\hline $\mathrm{MIP}^{\mathrm{a}}$ & 172 & 0.28 & 4.93 \\
$\mathrm{NIP}$ & 6.9 & 0.03 & 1.69 \\
$\mathrm{MIP}^{\mathrm{b}}$ & 166 & 0.21 & 5.05 \\
\hline
\end{tabular}

${ }^{\mathrm{a}}$ Leached polymers; ${ }^{\mathrm{b}}$ Unleached polymers.

FT-IR spectroscopic analysis of unleached and leached 4-aminophenol imprinted polymer materials were performed using $\mathrm{KBr}$ pellets (Figure 2). The content of the remaining carbon-carbon double bonds in the MIP is an important indication of polymerization extent. No band is present in the region of $1648-1638 \mathrm{~cm}^{-1}$, indicating the absence of vinyl groups in the polymerized materials. This confirms complete polymerization of vinyl groups. Meanwhile, other observations can be noticed. The IR spectra of the MIP $\left(3447,2949,1729,1160 \mathrm{~cm}^{-1}\right)$ shows typical porphyrin patterns, which is consistent with the porphyrinic backbone of hemin. The IR spectrum of unleached-MIP (Figure 2a) $\left(3435,2949,1729,1160 \mathrm{~cm}^{-1}\right)$ is very similar to that of the leached-MIP (Figure 2b), indicating molecular structure similarity. ${ }^{23}$

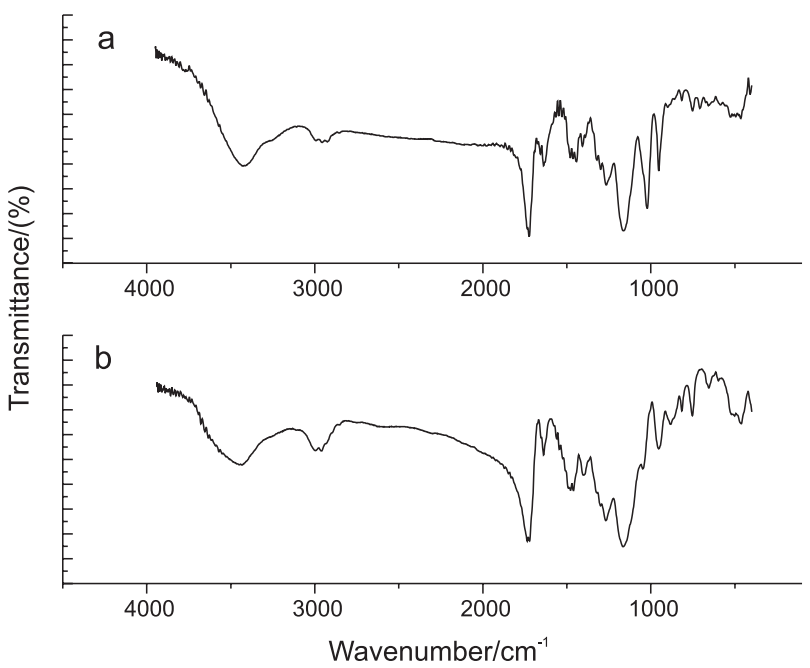

Figure 2. IR spectra of unleached (a) and leached (b) 4-APh imprinted polymer.

Thermogravimetric analysis profiles for unleached (curve a) an leached (curve b) polymer (Figure 3) show that decomposition of polymer particles starts at 140 and $250{ }^{\circ} \mathrm{C}$, respectively. This indicates rigidity of the leached MIP particles as compared to unleached MIP particles. The TG of unleached polymer material shows decomposition at $140{ }^{\circ} \mathrm{C}$ due to degradation of 4-aminophenol, and a new plateau starts at $220^{\circ} \mathrm{C}$ and extends to $240{ }^{\circ} \mathrm{C}$, where decomposition of the polymeric matrix starts. On the other hand, the decomposition in the leached polymeric material (curve b) starts at $250^{\circ} \mathrm{C}$, probably because it is more difficult to eliminate the bounds existing in the polymeric matrix. ${ }^{24}$

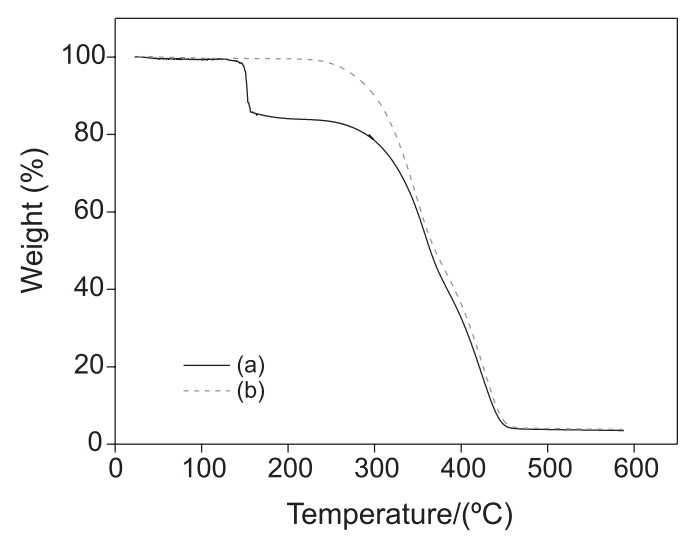

Figure 3. TG plots of unleached (a) and leached (b) 4-APh imprinted polymer.

The differential thermogram of both unleached (curve a) and leached (curve b) MIP particles (Figure 4) confirms the above inferences. Hence, thermal stability of the leached MIP particles is higher compared to unleached MIP material.

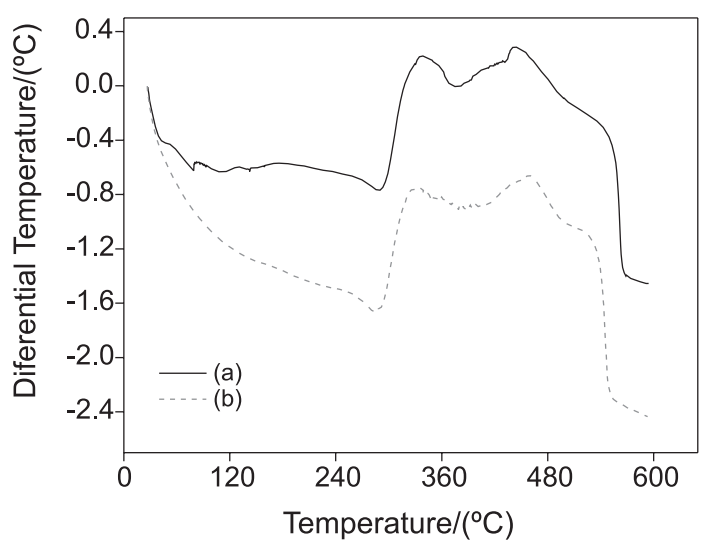

Figure 4. DTA plots of unleached (a) and leached (b) 4-APh imprinted polymer.

\section{Catalytic and kinetic effects of the imprinted polymers}

Since hemin is the essential factor for the catalytic reaction, its content was used as an index of "active sites" in the imprinted polymer. As is well known, iron porphyrins react with hydrogen peroxide, displaying both catalaseand peroxidase-like activities, and have the advantage of forming intermediate species similar to those formed during enzymatic processes. ${ }^{25,26}$ 
Based on these features, in this work the hemincontaining MIP was investigated for catalytic activity with $4-\mathrm{APh}$ as substrate in Tris- $\mathrm{HCl}$ buffer $(\mathrm{pH} 8.0$, $0.1 \mathrm{mmol} \mathrm{dm}^{-3}$ ). A dynamic curve typical of a catalytic reaction was observed in the system (Figure 5), from which we obtained characteristic parameters, such as Michalis-Menten constant $\left(K_{\mathrm{m}}\right)$ and the maximum rate $\left(V_{\max }\right)$, according to Lineweaver-Burk theory. ${ }^{27-29}$

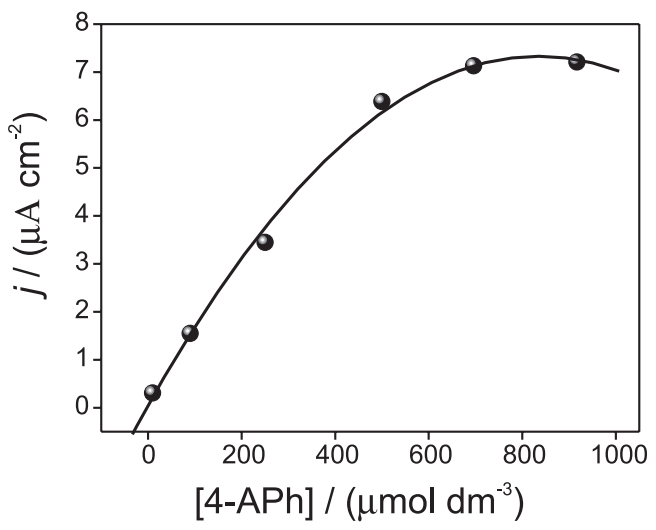

Figure 5. Typical dynamic profile of the catalytic reaction of 4-aminophenol catalyzed by the peroxidase-like MIP.

According to the theory of enzymatic catalysis, ${ }^{29}$ the Michaelis-Menten constant $\left(K_{\mathrm{m}}\right)$ represents the affinity of a given enzyme towards the substrate. The smaller the $K_{\mathrm{m}}$, the stronger the affinity will be, and the "favorite" substrate of a given enzyme will show the lowest $K_{\mathrm{m}}$ value. Thus, in the Michaelis-Menten model initial rates of reaction are plotted against the substrate concentration (4-APh) based on a hyperbolic relation as follows:

$\Delta j_{\mathrm{s}}=\frac{V_{\max }[4-A P h]}{\left([4-A P h]+K_{m}^{a p p}\right)}$

In order to have a linear relation , the Lineweaver-Burk equation is written as: ${ }^{30,31}$

$\frac{1}{\Delta j_{s}}=\frac{1}{V_{\max }}+\frac{K_{m}^{a p p}}{V_{\max }[4-A P h]}$

where $j_{s}$ is the current density in the steady-state after the addition of substrate, [4-APh] the substrate concentration in the bulk solution, $V_{\max }$ is the maximum rate measured under saturated substrate conditions (i.e. maximum current density measured undersaturated substrate conditions), and $K_{m}^{a p p}$ is the apparent Michaelis-Menten constant. A low $K_{\mathrm{m}}$ value indicates strong substrate binding. The values of $K_{\mathrm{m}}$ and $V_{\text {max }}$ (Figure 6) were calculated from the electrochemical version of the Lineweaver-Burk equation. From our experimental data, these values were calculated as $195.79 \mu \mathrm{mol} \mathrm{dm}{ }^{-3}$ and $6.53 \mu \mathrm{A} \mathrm{cm}^{-2}$, respectively.
Although the obtained $K_{\mathrm{m}}$ value is large in relation to the peroxidase enzyme $K_{\mathrm{m}}\left(1.5 \mu \mathrm{mol} \mathrm{dm}{ }^{-3}\right.$ for oxidation of phenolic compounds), ${ }^{32}$ it indicates potential for application of MIP-4-APh catalyst for analytical purposes. However, in native enzymes many difficulties in practical use exist in their sensitive properties such as instability against high temperature, organic solvents and serious $\mathrm{pH}$ conditions etc. Furthermore, the $K_{\mathrm{m}}$ value for imprinted polymer is lower than the value reported in the literature for systems containing naturally immobilized peroxidases, ${ }^{33-40}$ giving evidence for the higher sensitivity of the imprinted polymer. These results show that imprinted polymer could be used as a peroxidase mimicking catalyst, indicating that it could be an alternative for the peroxidase enzyme.

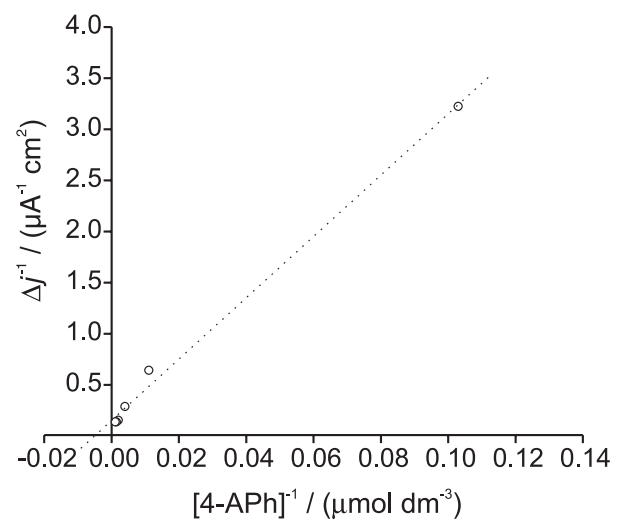

Figure 6. Lineweaver-Burk plot for MIP in the presence of different concentrations of $4-\mathrm{APh}$ in $0.1 \mathrm{mmol} \mathrm{dm}^{-3}$ Tris- $\mathrm{HCl}$ buffer at $\mathrm{pH} 8.0$.

\section{Conclusions}

A specific imprinted polymer for 4-APh was prepared by bulk polymerization, using the combination of hemin as important prosthetic group and two functional monomers. The prepared MIP revealed high affinity and selectivity toward its template. Notably, by taking advantage of the particular structures of hemin and the multiple-site interactions provided by plural co-monomers, it was possible to prepare a polymeric material for synthetic enzyme mimicking in a simple and inexpensive way. Physical and chemical characteristics of the polymer, such as pore surface area and pore size, SEM, FT-IR, TG and DTA, were found to be crucial for the application for MIP. These data showed that the MIP developed can be a valuable tool for the recognition of 4-APh. The imprinted polymer exhibited higher catalytic activity towards $4-\mathrm{APh}$.

\section{Acknowledgments}

The authors acknowledge financial support from the Fundação de Amparo à Pesquisa do Estado de São Paulo 
(FAPESP), the Conselho Nacional de Desenvolvimento Científico e Tecnológico (CNPq) and the Fundação de Amparo à Pesquisa do Estado de Minas Gerais (FAPEMIG). WJRS and PRL are indebted to FAPESP for fellowships. The authors are also indebted Prof. Carol H. Collins for English revision.

\section{References}

1. Sellergren, B.; Angew. Chem. Int. Ed. 2000, 39, 1031.

2. Wulff,G.; Angew. Chem. Int. Ed. 1995, 34, 1812.

3. Mosbach, K.; Ramström, O.; Biotechnology 1996, 14, 163.

4. Arshady, R.; Mosbach, K.; Makromol. Chem. 1981, $182,687$.

5. Brüggemann, O.; Anal. Chim. Acta 2001, 435, 197.

6. Wulff, G.; Chem. Rev. 2002, 102, 1.

7. Markowitz, M. A.; Kust, P. R.; Deng, G.; Schoen, P. E.; Dordick, J. S.; Clark, D. S.; Gaber, B. P.; Langmuir 2000, 16, 1759.

8. Ramstrom, O.; Mosbach, K.; Curr. Opin. Chem. Biol. 1999, 3, 759.

9. Lele, B. S.; Kulkarni, M. G.; Mashelkar, R. A.; React. Funct. Polym. 1999, 39, 37.

10. Suziki, A.; Tada, M.; Sasaki, T.; Shido, T.; Iwasawa, Y.; J. Mol. Catal. A: Chem. 2002, 182/183, 125.

11. Slade, C. J.; J. Mol. Catal. B: Enzym. 2000, 9, 97.

12. Okhuba, K.; Urata, Y.; Hirota, S.; Funakoshi, Y.; Sagawa, T.; Usui, S.; Yoshinaga, K.; J. Mol. Catal. 1995, 101, 111.

13. Wulff, G.; Gross, T.; Schonfeld, R.; Angew. Chem. Int. Ed. 1997, 36, 1961.

14. Bruggemann, O.; Biomol. Eng. 2001, 18, 1.

15. Santos, W. J. R.; Lima, P. R.; Tarley, C. R. T.; Kubota, L. T.; Anal. Bioanal. Chem. 2007, 389, 1919.

16. Nazari, K.; Shokrollahzadeh, S.; Mahmoudi, A.; Mesbahi, F.; Seyed-Matin, N.; Moosavi-Movahedi, A. A.; J. Mol. Catal. A: Chem. 2005, 239, 1.

17. Hay, R. W.; Bio-Inorganic Chemistry, Ellis Harwood Limited: New York, 1991.

18. Palmer, G. In The Porphyrins; Dolphin, D., ed.; Academic Press: New York, 1978.

19. Kamiya, N.; Goto, M.; Furusaki, S.; Biotechnol. Bioeng. 1999, 64, 502 .
20. Santos, W. J. R.; Lima, P. R.; Tarley, C. R. T.; Höehr, N. F.; Kubota, L. T.; Anal. Chim. Acta 2009, 631, 170.

21. Gregg, S. J.; Sing, K. S. W.; Adsorption, Surface Area and Porosity, $2^{\text {nd }}$ ed., Academic Press Inc.: London, 1982.

22. Voet, D.; Voet, J. G.; Biochemistry, $2^{\text {nd }}$ ed., Wiley: New York, 1995, p. 351.

23. Chen, Z.; Hua, Z.; Wang, J.; Guan, Y.; Zhao, M.; Li, Y.; Appl. Catal. A: Chem. 2007, 328, 252.

24. Duval, C.; Inorganic Thermogravimetric Analysis, Elsevier: New York, 1963.

25. De Vos, D. E., Jacobs, P. A.; Catal. Today 2000, 57, 105.

26. Meunier, B.; Bull. Soc. Chim. Fr. 1986, 4, 578.

27. Ci, Y. X.; Wang, F.; Fresenius J. Anal. Chem. 1991, 339, 46.

28. Lineweaver, H.; Burk, D.; J. Am. Chem. Soc. 1934, 56, 658.

29. Bergmeyer, H. U.; Bergmeyer, J.; Grabl, M.; Methods of Enzymatic Analysis, vol. I, $3^{\text {rd }}$ ed.; Verlag Chemie: Weinheim, 1983, p. 86.

30. Xiao, Y.; Ju, H. X.; Chen, H. Y.; Anal. Biochem. 2000, $278,22$.

31. Kamin, R. A.; Willson, G. S.; Anal. Chem. 1980, 52, 1198.

32. Kumar, N.; Tripathi, D. R.; Plant Peroxidase Newsletter 1999 , 15,45 .

33. Zhao, X.; Maia, Z.; Kanga, X.; Zou, X.; Biosens. Bioelectron. 2008, 23, 1032.

34. Xiao, Y.; Ju, H. X.; Chen, H. Y.; Anal. Biochem. 2000, 278, 22.

35. Ju, H. X.; Liu, S. Q.; Ge, B.; Lisdat, F.; Scheller, F. W.; Electroanalysis 2002, 14, 141.

36. Liu, S. Q.; Ju, H. X.; Anal. Biochem. 2002, 307, 110.

37. Wan, Q. L.; Lu, G. X.; Yang, B. J.; Biosens. Bioelectron. 2004, 19, 1269.

38. Fan, C.; Gao, Q.; Zhu, D.; Wagner, G.; Li, G.; Analyst 2001, 126, 1086.

39. Tong, Z.; Yuan, R;. Chai, Y.; Xie, Y.; Chen, S.; J. Biotechnol. 2007, 128, 567.

40. Kozan, J. V. B.; Silva, R. P.; Serrano, S. H. P.; Lima, A. W. O.; Angnes, L.; Anal. Chim. Acta 2007, 591, 200.

Received: August 11, 2008 Web Release Date: March 13, 2009

FAPESP helped in meeting the publication costs of this article. 